\title{
The effect of prepartum protein feeding on post- partum lactation performance of Ayrshire heifers and cows
}

\author{
A.T. Tesfa', T. Kokkonen', M. Tuori', T. Saukko², L-A. Lindberg ${ }^{2}$, \\ R. Pösö ${ }^{2}$, H. Saloniemi ${ }^{2}$ and L. Syrjälä-Qvist ${ }^{1}$
}

\author{
University of Helsinki \\ 'Department of Animal Science \\ Box 28, 00014, Helsinki, Finland \\ 'Department of Basic Veterinary Science \\ Box 57, 00014, Helsinki, Finland
}

(Reccived 26 June 2000; accepted 22 January 2001)

\section{ABSTRACT}

Thirty Ayrshire cows, 14 multiparous (MP-cows) and 16 heifers (heifers), were used to investigate the response of animal performance to prepartum rapeseed meal supplement (RSM). The basic diet was formulated from oats and barlcy (1:1 DM basis) and wilted grass silage. Both hejfers and MP-cows were paired by their expected date of calving to form two groups of each. One of each MP-cow pair (control cows; CC) and heifer pair (control heifers, CH) were offered $3 \mathrm{~kg} \mathrm{~d}^{-1}$ the basic diet without protein supplement. Part of the grain was replaced by $1.5 \mathrm{~kg} \mathrm{~d}^{-1} \mathrm{RSM}$ in the diet of the other pairs (test cows, TC; and test heifers, TH). Mineral supplement was fed at $250 \mathrm{~g} \mathrm{~d}^{-1}$ (heifers) and $300 \mathrm{~g} \mathrm{~d}^{-1}$ (MP-cows). Following parturition, all animals were offered similar lactation concentrate containing oats and barley $(64 \%)$, RSM (18\%) and molassed sugar beet pulp (18\%) with wilted grass silage. Pre- and postpartum blood samples were taken. Feed intake, body condition, body weight change, milk yield and composition were monitored.

Prepartum RSM supplement increased total feed intake of TH through increased voluntary silage intake. $\mathrm{CH}$ consumed less DM and lost more body weight during carly lactation but produced higher $(\mathrm{P}<0.09$ and $\mathrm{P}<0.02$ ) milk than the TH during 23-41 days (Period 2) and 42-60 days (Period 3) of lactation. The milk protein content of the same group was lower $(\mathrm{P}<0.04)$ during Period 3. Plasma and milk urea concentration was higher for the TH during $4-22$ days of lactation (Period 1) and Period 2. Prepartum RSM supplement did not significantly affect feed intake, milk yield or milk composition of MP-cows. 


\section{INTRODUCTION}

Prepartum protein supplement has influenced milk production in dairy goats (Sahilu et al., 1995) and dairy heifers (Tesfa et al., 1999) whereas Van Saun et al. (1993) and Wu et al. (1997) showed no relationship between prepartum protein supplement to improved performance of dairy cow. Besides improved performance in milk yield and composition, prepartum protein intake has also been associated with lower incidence of ketosis and retained placenta (Curtis et al., 1985). On the other hand, first-calving heifers have been found to be less responsive to protein supplementation than multiparous cows in terms of milk and protein yield (Thomas et al., 1981; Sutton et al., 1996). In both heifers and adult cows, during the late gestation, the need of the growing foctus for amino acids increases several folds (Bell, 1995) besides the need for other tissues, such as muscle and liver, for protein synthesis. Late gestation is also a period when most amino acids play a role in the regulation of several hormone's production and functions, thus shortage of amino acids may cause a change in the endocrine functions to affect nutrient intake and nutrient partitioning, which may, directly or in-directly, contribute postpartum performance of the animal. As Paquay et al. (1972, ref. Putnam and Varga, 1998) calculated earlier, an adult cow is able to store and mobilize greater than $15 \mathrm{~kg}$ of protein from different various protein and energy intakes.

It has also been observed that during the transitional period (1-3 weeks prepartum to 3 weeks postpartum) the high yielding cow is under enormous stress due to the marked changes in endocrine status to accommodate parturition and milk secretion (Bertics et aI., 1992; Grant and Albright, 1994; Grummer, 1995). Significant mobilization of maternal reserve protein occurs during the transitional period (Bell et al., 1995), if protein supply is in adequate.

Following parturition, the demand for amino acids by the mammary gland for the synthesis of milk protein and lactose exceeds the supply from feed, thus the animal mobilize protein reserve to supply amino acids for milk synthesis and also for gluconeogenesis (Bauman and Currie, 1980). In our previous studies with heifers fed prepartum extra protein supplement, we observed an increase in silage intake and in milk yield with no effect on milk protein yield or content (Tesfa et al., 1999) whereas Moorby and Dewhurst (1995) observed an increase in milk protein yield during the first 30 weeks of lactation. Therefore, the present experiment is designed to investigate the response of both first-calving heifers and multiparous cows to prepartum protein supplement in terms of pre- and postpartum blood metabolites, postpartum voluntary silage intake, body condition score and body weight change, as well as milk yield and composition. 


\section{MATERIAL AND METHODS}

\section{Animals and prepartum management}

Thirty Ayrshire cows, 16 first-calving heifers and 14 multiparous cows, were used in a completely randomised design. Each cow's metabolic energy requirement for maintenance was calculated as 0.51 MJ (MAFF, 1975; Tuori et al., 1996) $\mathrm{kg}^{-1}$ metabolic body weight $\left(\mathrm{BW}^{0.75}\right)$ with the weekly exponential adjustment for gestation requirement $(\mathrm{ARC}, 1984)$. The basal diet was formulated from wilted grass silage, oats and barley (1:1 DM basis), and or rapeseed meal (RSM). Both heifers and MP-cows were paired based on their anticipated calving date. During the prepartum period, one pair of cows ( 7 control cows, CC) and one pair of heifers ( 8 control heifers, $\mathrm{CH}$ ) were offered the control basal diet without RSM supplement. Part of the grain was replaced by $1.5 \mathrm{~kg} \mathrm{~d}^{-1} \mathrm{RSM}$ as a protein supplement in the diet of the other pairs (test cows, TC; and test heifers, TH). The animals were housed in a tie stall and fed individually. Grain was fed at 14.30 to the animals on a weckly stepped increment of $0.5 \mathrm{~kg}$ for un-supplemented diet and $0.375 \mathrm{~kg}$ for supplemented diet, to attain the total concentrate allowance of $3.0 \mathrm{~kg} \mathrm{~d}^{-1}$ at the time of calving. Wilted grass silage allowance of each animal was calculated as a difference between energy requirement and cnergy allowance from grain or grain with RSM. Silage feeding took place at 05.30 and $15.00 \mathrm{~h}$. The average intake of absorbable amino acid in the duodenum (AAT, $g$ $\left.\mathrm{d}^{-1}\right)$ was $692(\mathrm{CH}), 786(\mathrm{TH}), 750(\mathrm{CC})$ and $824(\mathrm{TC})$. In addition, $300 \mathrm{~g} \mathrm{~d}^{-1}(\mathrm{MP}$ cows) and $250 \mathrm{~g} \mathrm{~d}^{-1}$ (heifers) mineral supplement was fed. Since feeding was restricted, no feed refusals were observed.

\section{Postpartum feeding management}

Following parturition, all were offered similar lactation concentrate containing oats and barley $(64 \%)$, RSM $(18 \%)$ and molassed sugar beet pulp (18\%) for the first eight weeks of lactation. Daily concentrate allowance was gradually increased, over the period of 10 days, from $3 \mathrm{~kg} \mathrm{~d}^{-1}$ to $14.0 \mathrm{~kg} \mathrm{~d}^{-1}$ to all MP-cows and $11.0 \mathrm{~kg} \mathrm{~d}^{-1}$ to heifers. Concentrate was fed 4 times a day $(06.00,09.30,14.30$ and 19.30). All cows had access to ad libitum (5 to 10\% weigh backs) wilted grass silage at 06.30 and $15.00 \mathrm{~h}$ every day. In addition, $350 \mathrm{~g} \mathrm{~d}^{-1}$ (MP-cows) and $250 \mathrm{~g} \mathrm{~d}^{-1}$ (heifers) mineral (7.7\% calcium; $6.4 \%$ phosphorus; $2.9 \%$ magnesium and $3.5 \%$ sodium) supplement was fed. Offered feed and feed refusals of individual cow were recorded daily. 
Measurements, sampling and analysis

Body weights (BW) were recorded on 2 consecutive days at weck 4 and 1 prepartum and week 1,4 and 8 postpartum. All the cows were body condition scored (BCS) subjectively, by the same person, from 1 to 5 points according to Lowman et al. (1976) score.

Samples of grain, RSM and molassed sugar beet pulp were taken once every $4^{\text {th }}$ weeks for dry matter analysis. Silage was sampled every $2^{\text {nd }}$ week throughout the trial, in addition to when new silos were started, and when changes in silage DM were noted. Both pre- and postpartum feed samples were subjected to the standard feed analysis for DM organic matter, crude protein, ether extract, acid and neutral detergent fibres as previously reported by Tesfa et al. (1999).

The cows were milked twice daily and milk yield was recorded at each milking. Milk samples were collected on 4 consecutive day of milking during week 2,4 and 8 postpartum. The morning and afternoon samples were bulked in proportion to yield and analysed with an infrared (IR) milk analyser for fat, protein, casein, total non-protein nitrogen and lactose. Milk urea content was determined with an enzymatic colorimetric method (Rajamäki and Rauramaa, 1984). The cow's first heat after calving was monitored by visual detection of heat and the number of artificial inseminations (AI) required for each cow were recorded. The health of the animals was cared for and monitored by a veterinarian.

\section{Metabolic profile}

Blood samples were collected regularly $7 \mathrm{~h}$ after the morning meal during week 4 and 1 prepartum and 1, 4 and 8 postpartum, through puncture of the jugular vein. Blood samples for analysis of insulin and glucagon and for the determination of ketone bodies, urea and non-esterified fatty acids (NEFA) were collected and analysed according to methods previously reported by Tesfa et al. (1999).

\section{Statistical analysis}

Data for feed intake, liveweight change, milk yield and composition were separated in to three Periods as: Period $1=4-22 \mathrm{~d}$ postpartum, Period $2=23-41 \mathrm{~d}$ postpartum, and Period $3=42-60 \mathrm{~d}$ postpartum and analysed by analysis of variance using the SAS (1985) general models procedure. Plasma metabolite data were analysed by the analysis of variance using the repeated model of the SAS GLM. 


\section{RESULTS}

Feed intake, BCS and BW changes

Feed chemical composition and feed values is given in Table 1 and overall mean (LSM) feed intake of experimental animals both during pre- and postpartum is given in Table 2.

TABLE 1

Feed chemical composition and feed value

\begin{tabular}{|c|c|c|c|c|}
\hline & Silage & Grain & $\begin{array}{l}\text { Rapeseed } \\
\text { meal }\end{array}$ & $\begin{array}{l}\text { Molassed sugar } \\
\text { bect pulp** }\end{array}$ \\
\hline Dry matter, $\mathrm{g} \mathrm{kg}^{-1}$ & 261 & 890 & 887 & 872 \\
\hline \multicolumn{5}{|l|}{ Composition, $\mathrm{g} \mathrm{kg}^{-1} \mathrm{DM}$} \\
\hline organic matter & 910 & 970 & 923 & 943 \\
\hline ash & 90 & 30 & 77 & 57 \\
\hline crude protein & 164 & 130 & 354 & 114 \\
\hline acid hydrolysis ether extract & 44 & 49 & 61 & 14 \\
\hline neutral-detergent Fibre & 478 & 234 & 284 & 367 \\
\hline acid detergent fibre & 276 & 83 & 194 & 178 \\
\hline $\mathrm{ME}, \mathrm{MJ} / \mathrm{kg} \mathrm{DM}$ & 11.12 & 13.08 & 11.56 & 12.29 \\
\hline digestible crude protein & 164 & 100 & 298 & 78 \\
\hline AAT & 87 & 99 & 148 & 109 \\
\hline PBV & 14 & -32 & 127 & -64 \\
\hline \multicolumn{5}{|l|}{ Silage fermentation qualities } \\
\hline PH & 3.90 & & & \\
\hline lactic acid, $\mathrm{g} \mathrm{kg}^{-1} \mathrm{DM}$ & 51.7 & & & \\
\hline acetic acid, $\mathrm{g} \mathrm{kg}^{-1} \mathrm{DM}$ & 18.6 & & & \\
\hline sugar, $\mathrm{kg}^{-1} \mathrm{DM}$ & 9.1 & & & \\
\hline \multicolumn{5}{|l|}{ 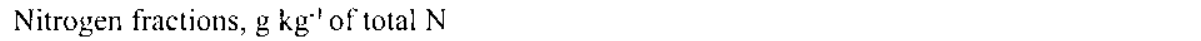 } \\
\hline soluble nitrogen & 490.4 & & & \\
\hline $\mathrm{NH}_{4}-\mathrm{N}$ & 40.4 & & & \\
\hline
\end{tabular}

* molassed sugar beet pulp was fed after calving; ME, metabolizable energy

\section{Heifers}

There was no difference in prepartum feed intake, as feeding was restricted. The postpartum overall voluntary silage DMI of the TH was significantly higher $(\mathrm{P}<0.03)$ and it remained to be constantly higher throughout the early lactation 
TABLE 2

Mean (LSM) feed intake of first calving heifers and multiparous cows during pre- and postpartum period

\begin{tabular}{|c|c|c|c|c|c|c|c|c|}
\hline \multirow{2}{*}{ Groups } & \multicolumn{3}{|c|}{ Heifers } & \multirow{2}{*}{$\mathrm{P}<$} & \multicolumn{3}{|c|}{ MP-Cows } & \multirow{2}{*}{$\mathrm{P}<$} \\
\hline & $\mathrm{CH}$ & $\mathrm{TH}$ & SE & & $\mathrm{CC}$ & $\mathrm{TC}$ & SE & \\
\hline \multicolumn{9}{|l|}{ Prepartum } \\
\hline total DMI, $\mathrm{kg} \mathrm{d}^{-1}$ & 7.86 & 8.25 & 0.62 & & 8.77 & 8.86 & 0.35 & \\
\hline silage, $\mathrm{kg} \mathrm{d}^{-1}$ & 6.00 & 6.2 & 0.56 & & 7.01 & 6.84 & 0.42 & \\
\hline grain, $\mathrm{kg} \mathrm{d}^{-1}$ & 1.86 & 0.72 & 0.33 & & 1.76 & 0.69 & 0.32 & \\
\hline $\mathrm{RSM}, \mathrm{kg} \mathrm{d}^{-1}$ & 0.00 & 1.33 & 0.02 & & 0.00 & 1.33 & 0.01 & \\
\hline $\mathrm{ME}, \mathrm{MJ} \mathrm{d}^{-1}$ & 89.4 & 89.9 & 6.93 & & 95.6 & 96.0 & 4.02 & \\
\hline AAT, $\mathrm{g} \mathrm{d}^{-1}$ & 692 & 786 & 79.03 & & 750 & 833 & 67.96 & \\
\hline $\mathrm{PBV}, \mathrm{g} \mathrm{d}^{-1}$ & -160 & 64.5 & 22.19 & & -166 & 57.1 & 23.25 & \\
\hline \multicolumn{9}{|l|}{ Postpartum } \\
\hline DMI, $\mathrm{kg} \mathrm{d}^{-1}$ & 15.9 & 17.0 & 1.40 & $* *$ & 20.9 & 20.4 & 1.46 & \\
\hline silage, $\mathrm{kg} \mathrm{d}^{-1}$ & 6.3 & 7.3 & 1.38 & ** & 8.8 & 8.2 & 1.42 & \\
\hline concentrate, $\mathrm{kg} \mathrm{d}^{-1}$ & 9.6 & 9.7 & 0.22 & & 12.1 & 12.2 & 0.19 & \\
\hline $\mathrm{ME}, \mathrm{MJ} \mathrm{d}^{-1}$ & 181 & 193 & 14.8 & $* *$ & 237 & 231 & 15.30 & \\
\hline $\mathrm{CP}, \mathrm{g} \mathrm{d}^{-1}$ & 2800 & 3035 & 408 & $*$ & 3575 & 3508 & 462.7 & \\
\hline AAT, $\mathrm{g} \mathrm{d}^{-1}$ & 1572 & 1670 & 168.5 & $*$ & 2051 & 2014 & 172.9 & \\
\hline PBV, $\mathrm{g} \mathrm{d}^{-1}$ & 210 & 255 & 66.86 & $* *$ & 295 & 270 & 61.4 & \\
\hline
\end{tabular}

note: SE, standard error of estimate; AAT, amino acids absorbed in the intestine; PBV, ruminal protein balance; ${ }^{*} \mathrm{P}<0.05 ; * * \mathrm{P}<0.01$
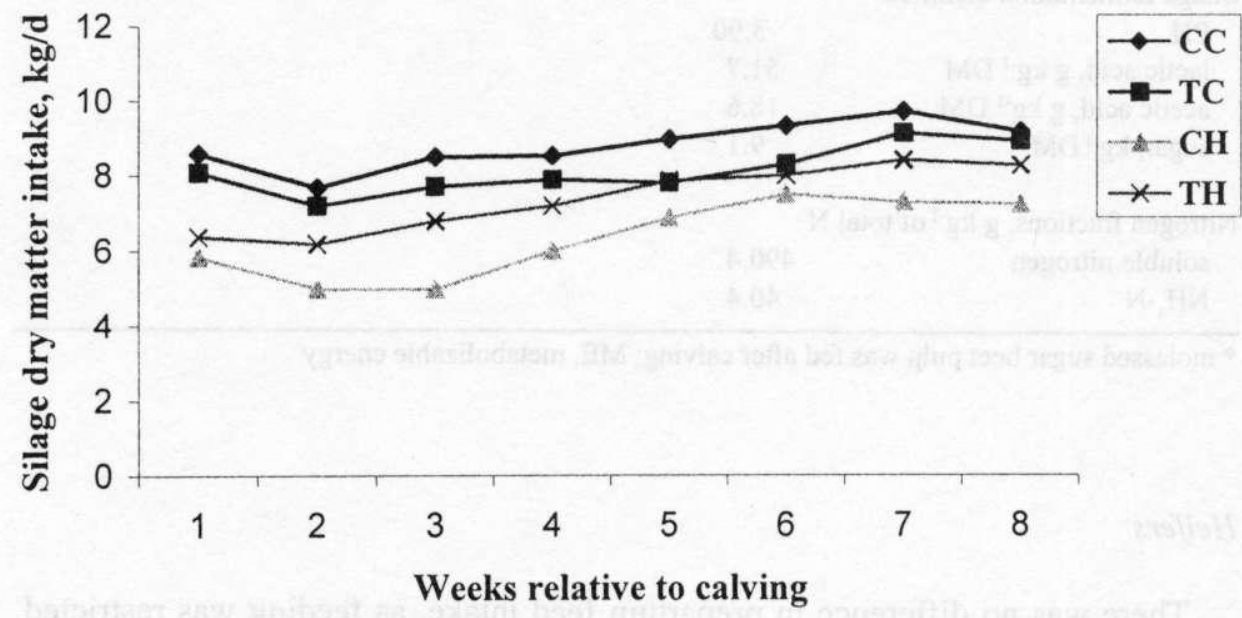

Figure 1. Effects of prepartum RSM feeding on postpartum silage intake of first calving heifers and multiparous cows 
(Figure 1) with the difference of $1.0 \mathrm{~kg} \mathrm{~d}^{-1}$ silage DMI compared to their counterparts. The higher silage intake of this group reflected on their overall intake of DM and $\mathrm{ME}(\mathrm{P}<0.04)$ as well as $\mathrm{CP}(\mathrm{P}<0.05)$. $\mathrm{CH}$ were under negative energy balance compared to $\mathrm{TH}$ during the early lactation and the difference was significantly high $(\mathrm{P}<0.03$ and $\mathrm{P}<0.09)$ during Periods 1 and 2 . The $\mathrm{BCS}$ of this group was lower $(\mathrm{P}<0.003$ and $\mathrm{P}<0.02)$ during Periods 2 and 3 (Table 3 ).

\section{Multiparous cows}

Though prepartum RSM did not significantly affect the feed intake of MP-cows, the voluntary silage DMI of TC tend to be lower than that of CC (Figure 1). TC lost more $(\mathrm{P}<0.08)$ body weight as well as BCS during Period 1 than $\mathrm{CC}$ (Table 3 ).

TABLE 3

Body condition score (BCS), body weight (initial, IBW; mean, MBW, and body weight change, $\mathrm{BWC}$ ) and number of artificial insemination required per conception per animal

\begin{tabular}{|c|c|c|c|c|c|c|c|c|}
\hline \multirow{2}{*}{ Time } & \multicolumn{3}{|c|}{ Heifers } & \multirow{2}{*}{$\mathrm{P}<$} & \multicolumn{2}{|c|}{ MP.Cows } & \multirow{2}{*}{ SE } & \multirow{2}{*}{$\mathrm{P}<$} \\
\hline & $\mathrm{CH}$ & TII & SE & & $\mathrm{CC}$ & $\mathrm{TC}$ & & \\
\hline \multicolumn{9}{|l|}{ BCS, prepartum } \\
\hline-4 weeks & 3.70 & 3.96 & 0.435 & & 3.69 & 3.19 & 0.547 & \\
\hline-1 week & 3.58 & 3.78 & 0.348 & & 3.76 & 3.23 & 0.532 & \# \\
\hline \multicolumn{9}{|c|}{ BCS, post partum } \\
\hline Pcriod 1 & 3.19 & 3.51 & 0.368 & $\#$ & 2.94 & 3.11 & 0.931 & \\
\hline Period 2 & 2.98 & 3.43 & 0.230 & $* * *$ & 3.40 & 2.94 & 0.481 & \\
\hline Period 3 & 2.89 & 3.26 & 0.281 & $* *$ & 3.27 & 2.90 & 0.373 & \# \\
\hline IBW, $\mathrm{kg} \mathrm{d}^{-1}$ & 568 & 590 & 58.59 & & 664 & 653 & 65.55 & \\
\hline \multicolumn{9}{|l|}{ MBW, $\mathrm{kg} \mathrm{d}^{-1}$} \\
\hline Period 1 & 530 & 571 & 62.24 & & 622 & 624 & 61.12 & \\
\hline Period 2 & 518 & 569 & 63.13 & & 621 & 611 & 59.79 & \\
\hline Period 3 & 520 & 576 & 64.91 & & 623 & 613 & 63.08 & \\
\hline \multicolumn{9}{|c|}{ Body weight change $\mathrm{kg} \mathrm{d} \cdot 1$} \\
\hline Period 1 & -1.11 & -0.72 & 1.26 & & -0.47 & -1.99 & 1.52 & \# \\
\hline Period 2 & -0.06 & 0.52 & 0.09 & \# & 0.33 & 0.68 & 0.37 & \\
\hline Pcriod 3 & 0.23 & 0.15 & 0.24 & & -0.12 & -0.12 & 0.10 & \\
\hline $\mathrm{Al} /$ conception & 2.4 & 3.0 & 2.04 & & 2.8 & 4.2 & 0.10 & \\
\hline
\end{tabular}

note: \# $\mathrm{P}<0.10 ; * * \mathrm{P}<0.01 ; * * * \mathrm{P}<0.001$ 


\section{Milk yield and milk composition}

Heifers. Prepartum RSM feeding did not improve subsequent milk yield of TH, in fact prepartum $\mathrm{RSM}$ deprived $\mathrm{CH}$ produced more milk $(\mathrm{P}<0.09$ and $\mathrm{P}<0.02)$ than the TH during Periods 2 and 3. There was no significant difference in milk fat, lactose and milk casein concentration. Milk protein content was higher $(\mathrm{P}<0.04)$ during Period 3 for the TH whereas milk NPN concentration increased $(\mathrm{P}<0.004$ and $\mathrm{P}<0.09$ ) during Periods 2 and 3. Prepartum RSM feeding significantly increased $(\mathrm{P}<0.01$ and $\mathrm{P}<0.09)$ the milk urea concentration during Periods 1 and 2 . The efficiency with which protein was utilized for milk protein production was higher $(\mathrm{P}<0.01$ and $\mathrm{P}<0.03)$ for $\mathrm{CH}$ during Periods 1 and 2 . Also the efficiency with which AAT was utilized for energy corrected milk production was higher $(\mathrm{P}<0.06$ and $\mathrm{P}<0.07)$ for $\mathrm{CH}$ than for $\mathrm{TH}$ during the same periods.

Multiparous cows. Though there was a positive response to preparum RSM feeding in terms of milk yield (Figure 2), the difference was not statistically significant. Also dietary treatments did not influence the efficiency with which AAT and feed protein were utilized for milk and milk protein production.

\section{Blood metabolites}

Heifers. Prepartum dietary regime did not affect prepartum plasma concentration of NEFA, BHB insulin and glucagon (Figures 3, 4, 5 and 6) in heifers. Howe-

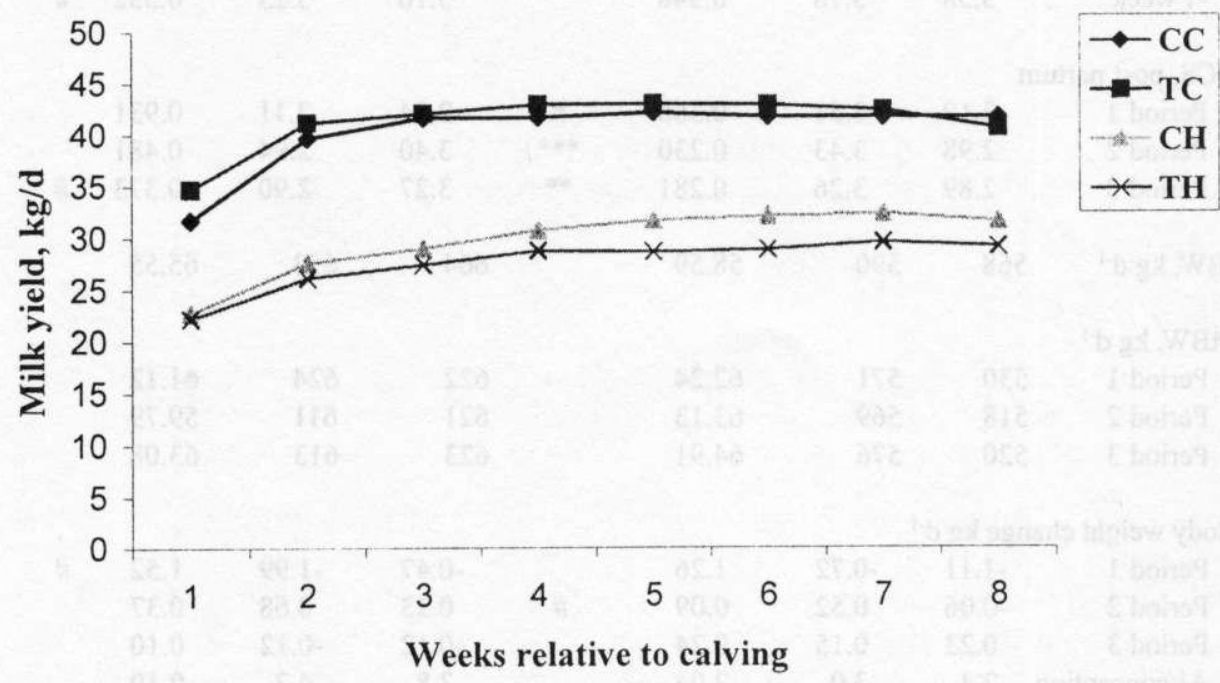

Figure 2. Milk yield response of heifers and multiparous cows to prepartum RSM feeding 


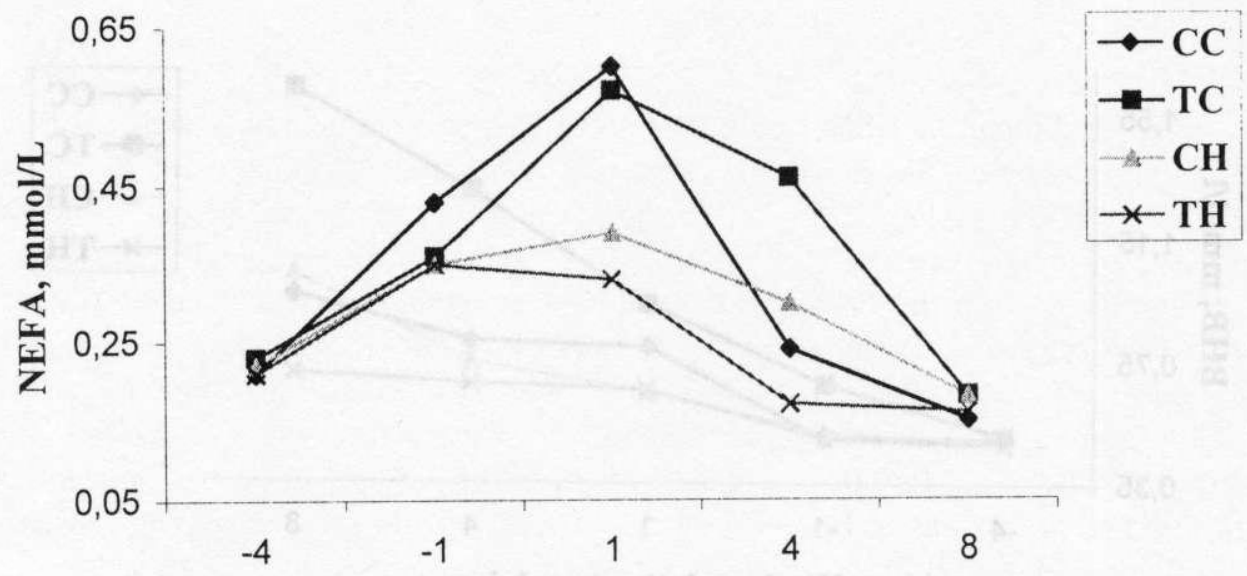

Weeks relative to calving

Figure 3. Plasma NEFA concentration as affected by prepartum RSM feeding (the difference between dietary treatment was significant $\mathrm{P}<0.006$ in heifers 4 weeks after calving)

TABLE 4 Effects of prepartum RSM feeding on feed $\left(\mathrm{kg} \mathrm{d}^{-1}\right)$ and nutrient intake of first calving heifers and multiparous cows during different periods

\begin{tabular}{|c|c|c|c|c|c|c|c|c|c|}
\hline \multirow{2}{*}{ Heifers } & \multicolumn{3}{|c|}{ Period 1} & \multicolumn{3}{|c|}{ Period 2} & \multicolumn{3}{|c|}{ Period 3} \\
\hline & $\mathrm{CH}$ & $\mathrm{TH}$ & SE & $\mathrm{CH}$ & $\mathrm{TH}$ & SE & $\mathrm{CH}$ & $\mathrm{TH}$ & SE \\
\hline Silage & 5.3 & 6.4 & 1.38 & 6.5 & 7.6 & 1.60 & 7.4 & 8.3 & 1.44 \\
\hline Concentrate & 9.0 & 9.2 & 0.31 & 9.8 & 9.9 & 0.39 & 10.0 & 9.9 & 0.12 \\
\hline Total DMI & 14.3 & 15.6 & 1.64 & 16.3 & 17.5 & 1.53 & 17.4 & 18.3 & 1.37 \\
\hline $\mathrm{ME}, \mathrm{MJ} \mathrm{d}^{-1}$ & 169.9 & 185.3 & 19.03 & 192.5 & 206.7 & 17.27 & 205.5 & 215.0 & 17.3 \\
\hline $\mathrm{CP}, \mathrm{g} \mathrm{d}^{-1}$ & 1930 & 2157 & 253 & 2236 & 2436 & 272 & 2381 & 2509 & 333 \\
\hline AAT, $\mathrm{g} \mathrm{d}^{-1}$ & 1427 & 1555 & 168 & 1615 & 1729 & 137 & 1719 & 1794 & 140 \\
\hline PVT, $g \mathrm{dv}$ & 130 & 201 & 73.9 & 203 & 263 & 121 & 218 & 254 & 168 \\
\hline \multirow{2}{*}{ MP-Cows } & \multicolumn{3}{|c|}{ Period 1} & \multicolumn{3}{|c|}{ Period 2} & \multicolumn{3}{|c|}{ Period 3} \\
\hline & $\mathrm{CH}$ & $\mathrm{TH}$ & SE & $\mathrm{CH}$ & $\mathrm{TH}$ & SE & $\mathrm{CH}$ & $\mathrm{TH}$ & SE \\
\hline Silage & 8.2 & 7.6 & 1.38 & 8.9 & 8.0 & & & 9.0 & 1.73 \\
\hline Concentrate & 10.9 & 11.4 & 0.36 & 12.6 & 12.6 & 0.22 & 12.7 & 12.7 & 0.10 \\
\hline Total DMI & 19.2 & 19.0 & 1.40 & 21.5 & 20.6 & 1.64 & 22.2 & 21.7 & 1.73 \\
\hline $\mathrm{ME}, \mathrm{MJ} \mathrm{d}^{-1}$ & 226.1 & 225.0 & 16.81 & 254.3 & 243.6 & 21.12 & 260.0 & 255.6 & 21.3 \\
\hline $\mathrm{CP}, \mathrm{d}^{-1}$ & 2554 & 2566 & 288 & 2855 & 2736 & 408 & 2893 & 2870 & 403 \\
\hline AAT, $d^{-1}$ & 1887 & 1886 & 137 & 2125 & 2041 & 174 & 2171 & 2140 & 172 \\
\hline PVT, $\mathrm{d}^{-1}$ & 187 & 191 & 147 & 182 & 165 & 204 & 161 & 175 & 199 \\
\hline
\end{tabular}




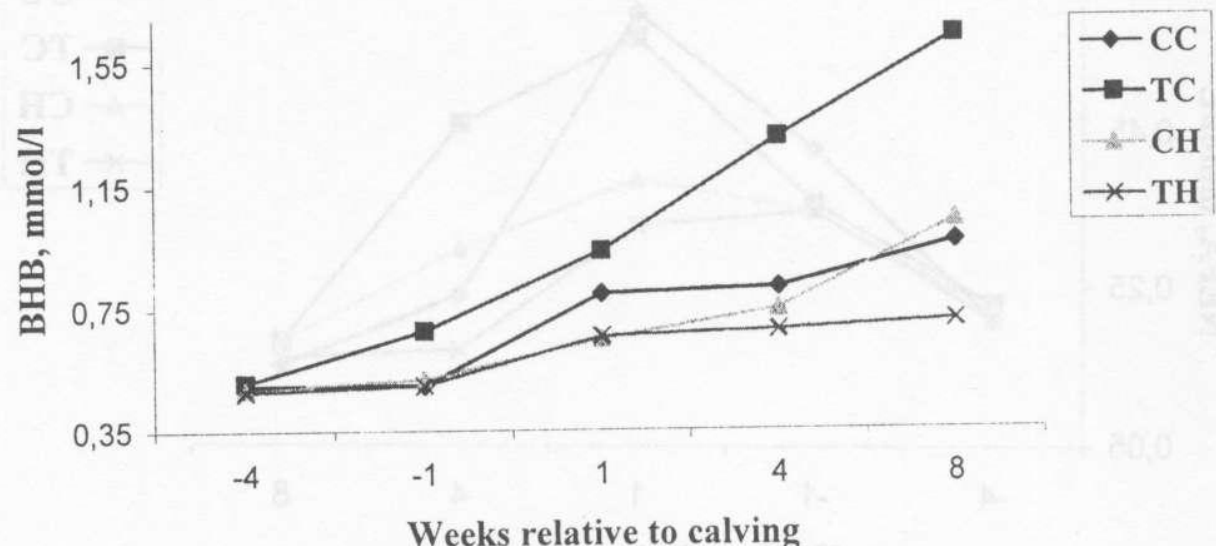

Figure 4. Plasma BHB concentration as affected by prepartum RSM feeding

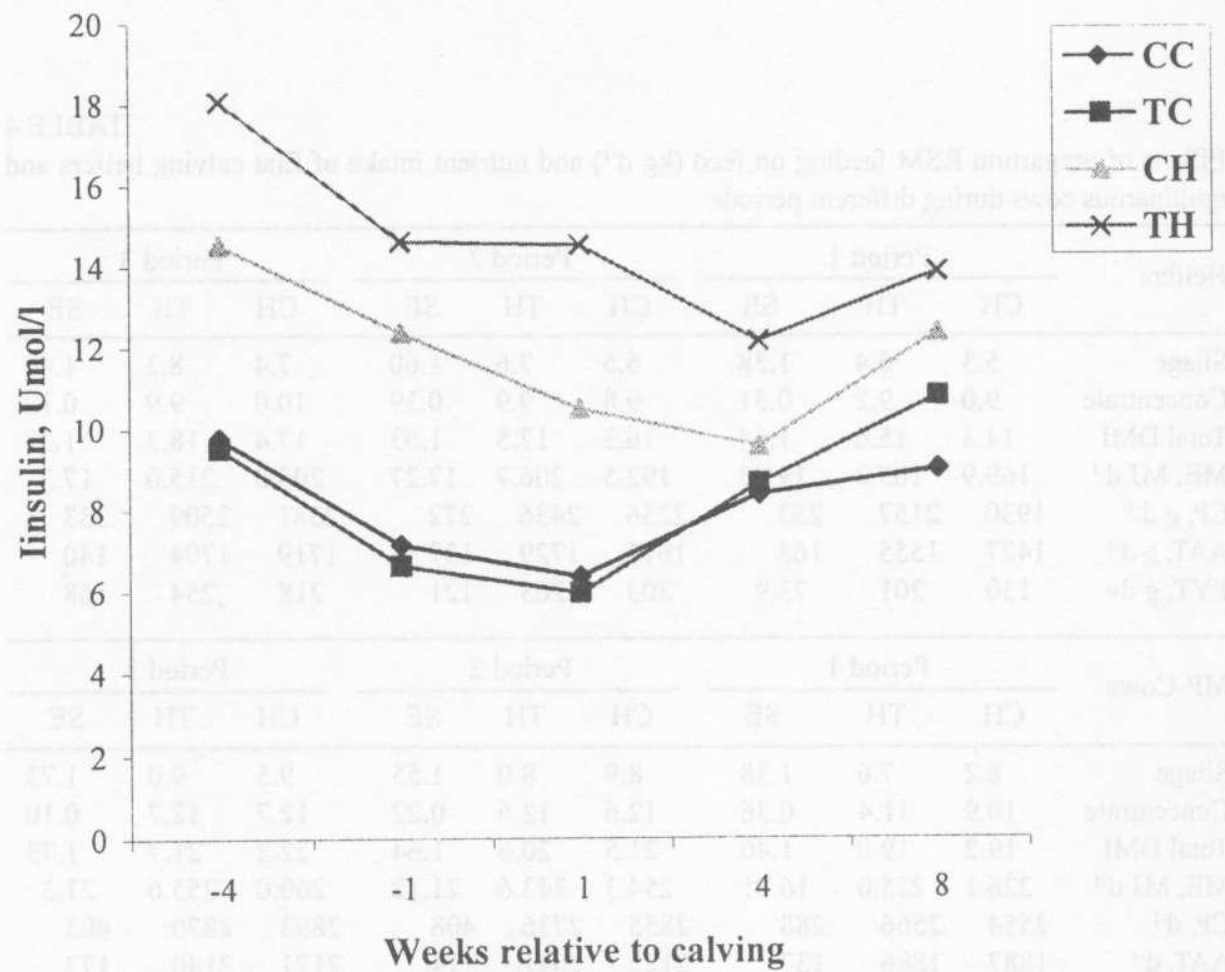

Figure 5. Plasma insulin concentration 


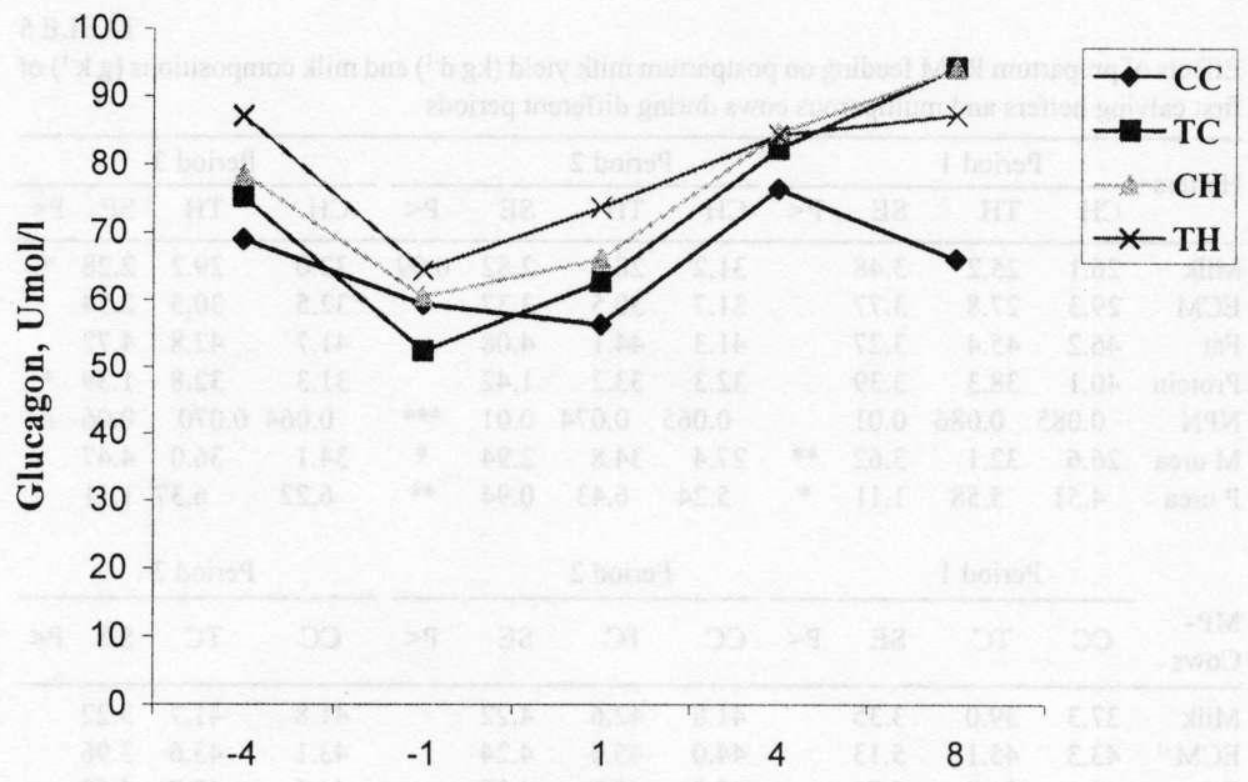

Weeks relative to calving

Figure 6. Plasma glucagon concentration

ver, the insulin concentration of TH tended to be higher than that of $\mathrm{CH}$ both during pre- and postpartum periods. Postpartum plasma NEFA concentration of $\mathrm{CH}$ was significantly higher $(\mathrm{P}<0.006)$ than that of $\mathrm{TH}$ during period 2 . $\mathrm{TH}$ had significantly higher $(\mathrm{P}<0.05$ and $\mathrm{P}<0.01)$ plasma urea concentration during Periods 1 and 2 (Table 5).

Multiparous cows. Starting 1 week before calving and thereafter for 8 week postpartum, plasma BHB concentration of TC was higher than that of CC (Figure 4). On the other hand, the plasma NEFA concentration tended to increase for both CC and TC starting 1 week before calving and reached peak at 1 week postpartum. That of CC decreased sharply between week 1 and 4 postpartum whereas that of TC remained higher $(\mathrm{P}<0.07)$ until week 4 and then dropped below the baseline value.

\section{DISCUSSION}

Results from studies with supplementary protein feeding effect on milk production and composition varied depending on the source, digestibility and amino acid composition of the protein as well as time of feeding (Julian et al., 1977; 
TABLE 5

Effects of prepartum RSM feeding on postpartum milk yield $\left(\mathrm{kg} \mathrm{d}^{-1}\right)$ and milk compositions $\left(\mathrm{g} \mathrm{k}^{-1}\right)$ of first calving heifers and multiparous cows during different periods

\begin{tabular}{|c|c|c|c|c|c|c|c|c|c|c|c|c|}
\hline \multirow{2}{*}{ Heifers } & \multicolumn{3}{|c|}{ Period 1} & \multicolumn{5}{|c|}{ Period 2} & \multicolumn{4}{|c|}{ Period 3} \\
\hline & $\mathrm{CH}$ & TH & $\mathrm{SE}$ & $\mathrm{P}<$ & $\mathrm{CH}$ & TH & $\mathrm{SE}$ & $\mathrm{P}<$ & $\mathrm{CH}$ & THI & SE & $\mathrm{P}<$ \\
\hline Milk & 26.1 & 25.2 & 3.48 & & 31.2 & 28.7 & 2.82 & 0.09 & 32.0 & 29.2 & 2.28 & $*$ \\
\hline $\mathrm{ECM}$ & 29.3 & 27.8 & 3.77 & & 31.7 & 30.5 & 3.37 & & 32.5 & 30.5 & 2.54 & \\
\hline Fat & 46.2 & 45.4 & 3.27 & & 41.3 & 44.1 & 4.08 & & 41.7 & 42.8 & 4.72 & \\
\hline Protein & 40.1 & 38.3 & 3.39 & & 32.3 & 33.2 & 1.42 & & 31.3 & 32.8 & 1.39 & $*$ \\
\hline NPN & 0.085 & 0.086 & 0.01 & & 0.065 & 0.074 & 0.01 & $* * *$ & 0.064 & 0.070 & 0.06 & $\#$ \\
\hline$M$ urea & 26.6 & 32.1 & 3.62 & $* *$ & 27.4 & 34.8 & 2.94 & $*$ & 34.1 & 36.0 & 4.47 & \\
\hline \multirow[t]{2}{*}{ P urea } & $4.5 i$ & 5.58 & 1.11 & $*$ & 5.24 & 6.43 & 0.94 & $* *$ & 6.22 & 6.37 & 1.11 & \\
\hline & \multicolumn{3}{|c|}{ Period 1} & \multicolumn{5}{|c|}{ Period 2} & \multicolumn{4}{|c|}{ Period 3} \\
\hline $\begin{array}{l}\text { MP- } \\
\text { Cows }\end{array}$ & $\mathrm{CC}$ & $\mathrm{TC}$ & SE & $\mathrm{P}<$ & $\mathrm{CC}$ & $\mathrm{TC}$ & SE & $\mathrm{P}<$ & $\mathrm{CC}$ & $\mathrm{TC}$ & $\mathrm{SE}$ & $\mathrm{P}<$ \\
\hline Milk & 37.3 & 39.0 & 3.35 & & 41.8 & 42.6 & 4.22 & & 41.8 & 41.7 & 3.22 & \\
\hline $\mathrm{ECM}^{-1}$ & 43.3 & 45.1 & 5.13 & & 44.0 & 45.6 & 4.24 & & 43.1 & 43.6 & 3.96 & \\
\hline Fat & 52.5 & 51.0 & 6.76 & & 45.2 & 47.2 & 4.09 & & 44.4 & 45.7 & 6.08 & \\
\hline Protein & 36.9 & 37.6 & 3.15 & & 31.6 & 31.2 & 2.16 & & 30.4 & 29.9 & 2.09 & \\
\hline NPN & 0.08 & 0.8 & 0.01 & & 0.07 & 0.06 & 0.01 & & 0.06 & 0.07 & 0.01 & \\
\hline M urea & 32.0 & 28.9 & 5.91 & & 32.6 & 29.3 & 4.72 & & 30.0 & 34.3 & 9.67 & \\
\hline P urea & 6.25 & 5.94 & 1.17 & & 6.24 & 6.70 & 1.19 & & 7.29 & 7.23 & 1.63 & \\
\hline P urea & 6.25 & 5.94 & 1.17 & & 6.24 & 6.70 & 1.19 & & 7.29 & 7.23 & 1.63 & \\
\hline
\end{tabular}

note: $P$ urea $=$ Plasma urea $\left(\mathrm{mmol} \mathrm{l}^{-1}\right)$ and $\mathrm{M}$ urea $=$ milk urea $\left(\mathrm{mg} 100 \mathrm{ml}^{-1}\right) ; \mathrm{NPN}\left(\mathrm{mg} \mathrm{l}^{-1}\right)$ \# $\mathrm{P}<0.10 ; * \mathrm{P}<0.5 ; * * \mathrm{P}<0.01 ; * * * \mathrm{P}<0.001$

Chew et al., 1984; Moorby et al., 1996; Tesfa et al., 1999). In the present study, the observed higher voluntary silage DMI response of TH to prepartum RSM supplement is in accordance with our earlier study (Tesfa et al., 1999), where prepartum supplementary RSM feeding improved postpartum silage intake of first calving heifers. Similar observation was reported by Chew et al. (1984) where prepartum supplementary non-protein nitrogen (urea) feeding with maize silage and hay also increased heifers dry matter intake. The higher voluntary feed intake of primiparous cows in this study could be speculated as improved microbial activity in the rumen due to the effect of prepartum supplementary protein feeding that facilitated the digestibility of gross energy (Oldham, 1980). On the other hand restricting early lactation protein supplement to $75 \%$ of recommendation did not affect nutrient digestibility but reduced DMI (Sutter et al., 1991) supporting the idea that protein supplement may have feed intake stimulating effect without affecting nutrient digestion. In case of our experimental 
heifers, higher silage intake may also account for the higher nutrient requirement of higher metabolic body weight since $\mathrm{TH}$ were heavier than the $\mathrm{CH}$ and lost very little BCS postpartum.

The low response in milk yield of the TH to the prepartum RSM feeding however is in disagreement with our previous findings (Tesfa et al., 1999), where milk yicld of heifers increased by $4 \mathrm{~kg}$ when the level of RSM was increased from 0.3 to $1.5 \mathrm{~kg} \mathrm{~d}^{-1}$. Owing to the higher feed intake, higher milk production should have been expected to occur as a consequence of a better nutrient supply to the mammary gland, similar to our previous observation. Or increased performance should have been achieved through mobilization of body reserve, since $\mathrm{TH}$ had higher initial body weight and BCS than $\mathrm{CH}$. However, due to the continuously high concentration of plasma insulin of $\mathrm{TH}$, the output of glucose from the liver was probably inhibited, and apparently uptake and incorporation of amino acids into muscle protein was increased thus promoted lipogenesis, which can be noted from the weight and BCS difference of the two groups. Our observation refutes that of Garnsworthy and Jones (1987) report where they concluded that fat cows or over conditioned cows have lower feed intake and higher mobilization of adipose tissue. This difference could be due to the age of the animal and priority of nutrient utilization by heifers compared to multiparous cows. Low response in milk yield to prepartum protein supplement may also mean that prepartum dietary regimen had less subsequent effect on first calving heifers in terms of milk production. Opposite to this report TH had higher DMI and higher NEFA concentration indicating that BCS and feed intake may not always correlate with NEFA concentration. Kunz and Blum (1985) also reported that the correlation between energy balance and plasma NEFA does not always exist.

In the present study, prepartum RSM deprived heifer's utilized feed protein more efficiently for milk protein production as well as AAT for energy corrected milk (ECM) compared with RSM supplemented heifers. According to the Finnish Feed Table (Tuori et al., 1995) the AAT requirement per kg ECM is $44 \mathrm{~g}$, but $\mathrm{CH}$ used less than $44 \mathrm{~g}$ of AAT kg-1 ECM (Table 6) though they were at a negative energy and AAT balance during Periods 1 and 2 . This may indicate that they had probably mobilized labial protein for milk production whereas the $\mathrm{TH}$ excreted the extra protein from RSM supplement and grass silage as milk urea (Table 6).

Urea-N production attributes to includes both absorbed amino acids and those coming from protein catabolism and was assumed to be $35 \%$ of the urea-N production in dairy cows during early lactation (Bruckental et al., 1980). In the present study, though the milk urea concentration of both groups was within the recommended range of Finnish Dairies, the higher level for TH clearly reflects the abundance of rumen degradable nitrogen. The higher milk urea concentra- 
TABLE 6 Energy balance (ME MJ) and efficiency with which metabolizable energy (ME) and protein (CP and AAT) were used for milk and milk protein production during 3 Periods of early lactation

\begin{tabular}{|c|c|c|c|c|c|c|c|c|c|c|c|}
\hline \multirow{2}{*}{ Heifers } & \multicolumn{4}{|c|}{ Period 1} & \multicolumn{4}{|c|}{ Period 2} & \multicolumn{3}{|c|}{ Period 3} \\
\hline & $\mathrm{Cll}$ & TII & $\mathrm{SE}$ & $\mathrm{P}<$ & $\mathrm{CI}$ & THI & SE & $\mathrm{P}<$ & $\mathrm{CH}$ & $\mathrm{IH}$ & $\mathrm{SE} \quad \mathrm{P}<$ \\
\hline \multicolumn{12}{|l|}{ Energy } \\
\hline \multicolumn{12}{|l|}{ AAT } \\
\hline balance & -105 & -28.7 & 66.6 & $* *$ & -73.2 & -14.6 & 60.1 & $\#$ & -55.0 & -2.62 & 65.2 \\
\hline \multicolumn{12}{|l|}{ Efficiency } \\
\hline & 0.82 & 0.70 & 0.11 & * & 0.74 & 0.66 & 0.09 & \# & 0.69 & 0.63 & 0.09 \\
\hline ATT/ECM & 42.6 & 45.1 & 2.46 & $*$ & 43.6 & 45.6 & 2.01 & $\ddot{H}$ & 44.3 & 45.9 & 2.13 \\
\hline$M P P_{1}$ & 0.42 & 0.35 & 0.05 & $* *$ & 0.35 & 0.30 & 0.04 & $* *$ & 0.33 & 0.30 & 0.04 \\
\hline Periods & \multicolumn{4}{|c|}{ Period 1} & \multicolumn{4}{|c|}{ Period 2} & \multicolumn{3}{|c|}{ Period 3} \\
\hline Cows & $\mathrm{CC}$ & $\mathrm{TC}$ & $\mathrm{SE}$ & $\mathrm{p}<$ & $\mathrm{CC}$ & $\mathrm{TC}$ & $\mathrm{SE}$ & $\mathrm{P}<$ & $\mathrm{CC}$ & $\mathrm{TC}$ & SE $\quad \mathrm{P}<$ \\
\hline \multicolumn{12}{|l|}{ Energy } \\
\hline \multicolumn{12}{|l|}{ AAT } \\
\hline balance & -181.2 & -222.9 & 30 & & -96.0 & -159.0 & 90.1 & & -61.3 & -86.0 & 84.7 \\
\hline \multicolumn{12}{|l|}{ Efficiency } \\
\hline $\mathrm{K}_{1}$ & 0.85 & 0.89 & 0.16 & & 0.73 & 0.81 & 0.10 & & 0.70 & 0.71 & 0.09 \\
\hline ATT/ECM & 41.0 & 40.6 & 2.66 & & 42.8 & 41.7 & 1.84 & & 43.6 & 43.2 & 1.86 \\
\hline $\mathrm{MPP}_{1}$ & 0.42 & 0.45 & 0.07 & & 0.36 & 0.38 & 0.06 & & 0.34 & 0.34 & 0.04 \\
\hline
\end{tabular}

nole: $\mathrm{K}_{1}=$ (energy corrected milk $\times 3.14$ ) $/ \mathrm{ME}$ intake $-0.51 \times \mathrm{BW}^{16.34}$; AAT $/ \mathrm{ECM}=\mathrm{g} \mathrm{AAT} / \mathrm{kg} \mathrm{FCM}$; $M P P_{1}=$ milk protein, $g /$ crude protein intake

${ }^{*} \mathrm{P}<0.05 ;{ }^{* *} 0.01 ; \# \mathrm{P}<0.10$

tion could be speculated as low hepatic gluconeogenesis (not measured) of absorbed amino acids to supply the required glucose by the mammary gland for milk production, thus excess nitrogen was excreted as milk urea. Similarly, the increase in milk NPN concentration is also a reflection of higher plasma urea concentration.

Prepartum RSM supplement for multiparous cows had less significance in terms of milk yield which is similar to previous reports (Van Saun, 1993; Wu, 1997; Putnam and Varga, 1998). It did not also improved milk composition as well as the efficiency with which nutrient has been utilized for milk production to indicate that prepartum nutrient allowance of $0.51 \mathrm{MJ} \mathrm{BW}$ B $^{0.75}$ with exponential adjustment for foetal growth is sufficient to support the onset of lactation when the initial body condition is above 3.10 (Table 3). CC had higher prepartum BCS and NEFA concentration as prepartum BCS may influence prepartum NEFA concentration (Reid et al., 1986). Despite an increase in NEFA concentra- 
tion, prepartum RSM deprived cows faster increased voluntary silage intake (Figure 1) capacity after calving compared to prepartum protein supplemented counterparts. On the other hand, despite continuous lose of BCS and higher plasma BHB concentration starting 1 weck before calving, the test cows did not show detectable case of ketosis or other metabolic disorders due to treatment differences.

\section{CONCLUSIONS}

Prepartum protein supplement did stimulate postpartum voluntary feed intake in first calving heifers but not in multiparous cows. It did not stimulate milk production in early lactation in both age groups. It however, increased plasma and milk urea concentration in heifers. High plasma concentration of urea may affect subsequent breeding parameters of cows as well as excess nitrogen excretion is also an environmental risk. Our study concludes that the current Finnish Feed Table (Tuori et al., 1996) nutrient requirement for gestation is enough to support maternal protein balance during gestation and the onset of lactation.

\section{REFERENCES}

ARC, 1984. The Nutrient Requirement of Ruminant Livestock. Supplement. No.1. Technical Review by Agricultural Research Council Working Party. Commonwealth Agriculture Bureau, Farnham Royal (UK), pp. 45

Bauman D.E., Currie W.B., 1980. Partitioning of nutrient during pregnancy and lactation, a review of mechanisms involving homeostasis and homeorhesis. J. Dairy Sci. 63, 1514-1529

Bell A.W., [995. Regulation of organic nutrient metabolism during transition from late pregnancy to early lactation. J. Anim. Sci. 73, 2804-2819

Bertics S., Grummer R., Cadorniga-Valino C., Stoddard E., 1992. Effect of prepartum dry matter intake on liver triglyceride concentration and early lactation. J. Dairy Sci. 75, 1914-1922

Bruckental I., Oldham J., Sutton J., 1980. Glucose and urea kinetics in cows in early lactation. Brit. J. Nutr. $44,33-45$

Chew B., Murdock F., Riley R., Hillers J., 1984. Influence of prepartum dietary crude protein on growth hormone, insulin, reproduction and lactation of dairy cows. J. Dairy Sci. 67, 270-275

Curtis C.R., Erb II.N., Sniffen C.J., Smith R.D., Kronfeld D.S., 1985. Path analysis of dry period nutrition, postpartum metabolic disorder, and mastitis in Holstcin cow. J. Dairy Sci. 68, 23472360

Garnsworthy P.C., Jones G.P., 1987. The influence of body condition at calving and dictary protein supply on voluntary food intake and performance in dairy cows. Anim. Prod. 44, 347-353

Grant R.J., Albright J.L., 1994. Feeding behaviour and management factor during the transition period in dairy cattle. J. Anim. Sci. 73, 2791-2803 
Grummer R. R., 1995. Impact of changes in organic nutrient metabolism on fecding the transition dairy cow. J. Anim. Sci. 73, 2820-2833

Kunz. P.L., Blum J.W., Hart I.C., Bickel H., Landis J., 1985. Effects of different energy intake before and after calving on food intake, performance and blood hormones and metabolites in dairy cows. Anim. Prod. 219-231

Lowman B.G., Scott N.A., Sommerville S.H., 1976. Condition scoring of cattle. East Scotland College of Agriculture, Bull. No. 6

MAFF, 1975. Encrgy Allowance and Feeding Systems for Ruminants. Tech. Bull. No 33. London, pp. 79

Moorby J.M., Dewhurst R.J., 1995. The impact of dry period feeding on subsequent lactation performance in dairy cows. Book of Abstracts, $46^{\text {th }}$ Annual Meeting of the European Association for Animal Production. Prague, Paper NC1.1

Oldham J.D., 1980. Protein and high yielding cow. In: W.H. Broster, C.L. Johnson, J.C. Tyler (Editors). Feeding Strategies for Dairy Cows. Agricultural Research Council, London, pp. 7.7-7.19

Rajamäki S., Rauramaa A., 1984. The automated determination of urea in milk. Finn. Chem. Lett. 2, $47-48$

Reid I.M., Roberts C.J., Treacher R.J., Williams L.A., 1986. Effect of body condition at calving on Tissue mobilisation, development of fatty liver and blood chemistry of dairy cows. Anim. Prod. $43,7-15$

Putnam D.E., Varga G.A., 1998. Protein density and its influence on metabolite concentration and nitrogen retention by Holstein cows in late gestation. J. Dairy Sci. 81, 1608-1618

Sahilu T., Hart S.P., Le-Trong T., Jia Z., Dawson L., Gibson T., 1995. Influence of prepartum protein and energy concentration for dairy goats during pregnancy and early lactation. J. Dairy Sci. 78, $378-387$

SAS, 1985. SAS User's Guide, Statistics. $5^{\text {th }}$ Edition. SAS Institute Inc. Carry, NC

Sutter F., Bickel H ., Wenk C., 1991. Energy and protein metabolism at the onset of lactation in dairy Cows. In: C. Wenk, M. Boessinger (Editors). Energy Metabolism of Farm Animals. EAAP Publication, No.58. Switerland, p. 488

Sutton J.D., Aston K., Beever D.E., Dhanon M.S., 1996. Milk production from grass silage diets. Effects of high protein concentrates for lactating heifers and cows on intake, milk production and milk nitrogen fraction. Anim. Sci. 62, 207-215

Tesfa A.T., Tuori M., Syrjälä-Qvist L., Pösö R., Saloniemi H., Heinonen K., Kivilahti K., Saukko T., Lindberg L.-A., 1999. The influence of dry period feeding on liver fat and postpartum performance of dairy cows. Anim. Feed Sci. Tech. 76, 275-295

Thomas C., Aston K., Tayler J.C., Daley S.R. Osboum D.F., 1981. Milk production from silage. 1. The influence of an additive containing formaldehyde and formic acid on the response of lactaling heifers and cows to supplementary protein. Anim. Prod. 32, 285-295

Treacher R.J., Reid I.M., Roberts C.J., 1986. Effects of body condition at calving on health and performance of dairy cows. Anim. Prod. 43, 1-6

Tuori M., Kaustell K., Valaja J., Aimonen E., Saarisalo E., Huhtanen P., 1996. Feed Tables and Feeding Recommendations (in Finnish). 2" Edition. Helsinki

Van Saun R.J., Idelman S.C., Sniffen C.J., 1993. Effect of undegradable protein amount fed prepartum on postpartum production in first lactation Holstein cows. J. Dairy Sci. 76, 236-244

Wu Z., Fisher R.J., Polan C.E., Schwab C.G., 1997. Lactation performance of cows fed low or high ruminally undegradable protein prepartum and supplemental methionine and lysine postpartum. J. Dairy Sci. $80,722-729$ 


\section{STRESZCZENIE}

\section{Wplyw poziomu bialka w dawkach skarmianych przed wycielaniem na wyniki laktacji jalówek i krów Ayrshire}

U trzydziestu krów Ayrshire, 14 wieloródek (MP-krowy) i 16 jałówek (H), badano reakcję zwierząt na podawanie przed wycieleniem paszy uzupełnionej śrutą rzepakową (RSM). Podstawowa dawka składała się z owsa i jęczmienia (1:1 w s.m.) oraz przewiędniętej kiszonki z traw. Tak jałówki jak i krowy dobierano parami na podstawie oczekiwanego terminu wycielenia i dzielono na dwie grupy. Jedna z nich: krowy (kontrolne, $\mathrm{CC}$ ) i jałówki kontrolne $(\mathrm{CH})$ otrzymywały po 3 kg dawki podstawowej na dzień, bez dodatku paszy białkowej. W dawkach dla drugiej grupy część ziarna zastąpiono RSM, w ilości 1,5 kg /dzień (krowy doświadczalne - TC i jałówki doświadczalne - TH). Dawki uzupełniano mieszankę mineralną: $250 \mathrm{~g} / \mathrm{dzień}$ - jałówki i $300 \mathrm{~g} / \mathrm{dzien}$ - krowy. Po wycieleniu wszystkie krowy otrzymywały taką samą mieszankę treściwą, przeznaczoną na okres laktacji, o następującym składzie: owies i jęczmień (64\%), RSM (18\%) i melasowane wysłodki buraczane (18\%), oraz przewiędniętą kiszonkę z traw. Przed i po wycieleniu pobierano próby krwi. Oznaczano pobranie paszy, kondycję zwierząt, zmiany m.c., wydajność i skład mleka.

Dodatek RSM przed wycieleniem zwiększył u TH pobranie paszy, poprzez zwiększenie pobrania kiszonki. CH pobierały mniej s.m. i traciły więcej na wadze w okresie wczesnej laktacji, lecz produkowały więcej $(\mathrm{P}<0,09$ i $\mathrm{P}<0,02)$ mleka niż TH między 23 a 41 dniem (Okres 2) i 42 a 60 dniem (Okres 3) laktacji. Zawartość białka w mleku krów z tej samej grupy była mniejsza $(\mathrm{P}<0,04)$ w Okresie 3. Stężenie mocznika w plazmie krwi i mleku było wyższe u TH w pierwszym (4-22 dni) i drugim okresie laktacji. Dodatek do dawek RSM przed wycieleniem nie miał istotnego wpływu na pobranie paszy, wydajność i skład mleka krów MP. 